\title{
Pendidikan Islam dalam GBHN dan Realitas Kebangsaan
}

\author{
Abdul Munir Mulkhan
}

\section{Pendahuluan}

ecara khusus, GBHN 1993 menekankan pentingnya pengembangan ilmu pengetahuan dan teknologi (iptek) dan peningkatan kualitas sumber daya manusia (SDM). Kedua masalah ini penting dijadikan bahan pengembangan strategi dan kebijakan pendidikan Islam. Namun kajian lebih mendasar dan kritis perlu dilakukan terhadap konsep pendidikan islam. Juga terhadap berbagai konsep pembangunan, khususnya mengenai masalah yang berkaitan dengan pendidikan.

Namun, kritik ulang atas wawasan keagamaan mengenai iptek dan otoritas manusia dalam pendidikan, peningkatan kualitas SDM dan pengembangan iptek, harus dilakukan dalam pengembangan strategi kebijakan pendidikan dalam realitas kebangsaan tersebut di atas. Pendekatan normatif dan ideologis seperti selama ini hanya akan menyebabkan pendidikan islam bersifat reaktif dan sulit berfungsi memberi arah dan panduan kehidupan kebangsaan. Melalui pendekatan yang lebih kultural, GBHN telah memberi banyak peluang realisasi fungsi paradigmatik pendidikan Islam dalam kehidupan bangsa dan kenegaraan.
Walaupun demikian, banyak rumusan GBHN yang masih memerlukan penajaman sesuai pendekatan kultural di atas. Ketakwaan terhadap Tuhan Yang Maha Esa merupakan nilai fundamental pembangunan iptek dan SDM. Namun, rumusan yang banyak diketemukan dalam GBHN 1993 ini juga masih bersifat normatif yang masih memerlukan perumusan lebih operasional, terutama dalam kaitannya dengan pendidikan, khususnya pendidikan Islam. Selain itu, terdapat beberapa rumusan yang memerlukan penegasan nilai (kultural/paradigmatik) sehingga tidak mengalami penyimpangan dalam berbagai praktek pembangunan.

Semuanya memerlukan penegasan posisi iptek dalam peningkatan kualitas keyakinan tauhid. Dan sebaliknya, perlu rumusan teoritis fungsi keyakinan tauhid dalam peningkatan kualitas SDM. Namun, fungsi dan kewenangan pendidikan dalam peningkatan kualitas SDM dan keyakinan tauhid, tidak kalah mendesaknya untuk diperjelas.

Posisi strategis pendidikan Islam (pendidikan agama Islam), baik sebagai lembaga atau suatu bidang studi akan ditentukan oleh fungsinya dalam memenuhi kebutuhan kehidupan umat dan masyarakat bangsa secara luas. Sementara itu kebu- 
Topik: Pendidikan Islam dalam GBHN dan Realitas Kebangsaan, Abdul Munir Mulkhan

tuhan umat dan masyarakat terus berkembang searah perubahan kehidupan yang semakin global. Karenanya, pendidikan Islam harus memperhatikan realitas obyektif dan prediksi mengenai masa depan masyarakat dan bangsa tersebut.

Dasar strategi itu menjadi semakin penting dalam perkembangan masyarakat yang semakin global, mandiri, bebas dan kritis. Dalam situasi ini setiap orang akan dapat mengambil keputusan tindakan berdasar informasi dari ribuan penjuru (Naisbitt, Global Paradox, Binarupa Aksara, 1994). Peradaban manusia itu kini telah melewati masa kedewasaan sejak renaisans dan aufklarung terutama sesudah revolusi informasi dan rekayasa genetik.

Sumber informasi keagamaan yang selama ini terbatas dari buku teks klasik, ulama dan atau kyai serta lembaga keagamaan, terus mencair melentur dan terbuka lebar. Pola kehidupan manusia dan bangsa pun berubah semakin cepat dalam rentang waktu yang sulit diukur. Pendidikan, khususnya pendidikan Islam yang disusun dari nilai-nilai klasik semakin cepat usang dan ketinggalan zaman.

Karena itulah strategi dan kebijakan pendidikan Islam perlu terus diperbaharui secara dinamis. Untuk itu konsep, tujuan dan metodologi pendidikan Islam perlu ditinjau ulang secara kritis. Demikian pula wawasan keagamaan dan tauhid mengenai iptek dan kemanusiaan serta sejarah dan kebudayaan.

Strategi dan kebijakan pendidikan Islam di Indonesia, dapat dikembangkan berdasar kajian kritis terhadap konsep pembangunan dalam GBHN. Namun, persoalan mendesak yang segera perlu dikaji ialah memperjelas posisi pendidikan Islam dalam sistem pendidikan nasional dalam kaitannya dengan konsep dan kebijakan pembangunan seperti tertuang dalam GBHN itu. Tanpa upaya demikian, strategi dan kebi- jakan pendidikan Islam, dapat terlepas dan tidak relevan dengan persoalan yang dihadapi umat dan bangsa.

Untuk itu, posisi iptek bukan sekedar pelengkap pendidikan tauhid yang diletakkan secara terpisah dari iptek. Selama ini, pendidikan tauhid sebagai inti pendidikan Islam dianggap dapat dipenuhi tanpa iptek, atau sebaliknya. Peran manusia di dalam pendidikan tauhid itu pun kurang jelas sehingga pendidikan Islam terlepas dari dinamika kebudayaan, iptek dan kemanusiaan. Bahasan teoritis sulit diketemukan, sekalipun dalam lembaga pendidikan tinggi Islam yang menjadikan pendidikan sebagai kajian utama.

Selama ini, informasi ke-Islam-an dalam 30 juz Al Quran dan Sunnah secara keseluruhan dijadikan bahan seluruh jenis, jenjang dan jalur pendidikan Islam. Hal ini masih ditambah berbagai ilmu yáng dipandang sebagai ilmu agama seperti: figh, kalam, tafsir, ibadah, akhlaq dan masalah keimanan. Akibatnya, pendidikan Islam keberatan beban dan evaluası sulit dilaksanakan dan dikembangkan.

Pandangan dan sikap itu menjadikan problem pendidikan Islam terperangkap jumlah jam dan frekuensi tatap muka gurumurid. Hal ini mengakibatkan penambahan jumlah jam, menjadi tuntutan politik pengembangan pendidikan Islam sepanjang sejarah. Penambahan jam yang semakin besar, dianggap sebagai kunci penyelesaian persoalan pendidikan Islam.

Masalah ke-Islam-an dan keyakinan tauhid pun dianggap sebagai persoalan yang hanya berkaitan dengan apa yang selama inj dikenal sebagai ilmu agama dan ilmu lain sejenis. Islam seolah hanya berurusan dengan hal-hal tersebut tanpa terkait dengan kebutuhan obyektif seperti makan, minum dan rumah. Pengolahan alam, sosial, ekonomi dan politik serta berbagai persoalan kebudayaan dianggap di luar 
Topik: Pendidikan Islam dalam GBHN dan Realitas Kebangsaan, Abdul Munir Mulkhan

masalah ke-Islam-an dan problem pendidikan Islam.

Selain itu, tujuan pendidikan Islam dirumuskan tanpa kaitan iptek dan kemanusiaan tersebut. Konsep tujuan ke-takwaan atau ke-insankamil-an serta ke-pribadimuslim-an dianggap dapat menyelesaikan seluruh problem pendidikan Islam di luar masalah riel kemanusiaan dan kebangsaan yang amat beragam. Sebaliknya, pendidikan tauhid harus dikembangkan sebagai wacana pemikiran teoritis dan iptek itu sendiri. Dari sinilah dapat dikembangkan konsep dan strategi kebijakan pendidikan Islam yang tidak hanya relevan bagi kehidupan bangsa tetapi juga bagi peradaban global.

\section{Menemukan Kembali Peran Pendidikan Islam}

Sejarah Islam pernah melahirkan pemikir dan masyarakat yang berperan kreatif dalam pergaulan dunia lebih luas. Pendidikan merupakan faktor terpenting (Nasr, Islam Tradisi, Pustaka, 1994) yang menyertai tiap perkembangan masyarakat dan bangsa. Demikian pula peningkatan kualitas profesional SDM dalam menyelesaikan berbagai persoalan yang dihadapi masyarakat dan bangsa.

Dengan pendidikan, iptek dikembangkan, tujuan ideal manusia dan bangsa diperjuangkan, sehingga kehidupan warga negara semakin sejahtera lahir dan batin. Bangsa berkemajuan teknologis, makmur secara ekonomis dan berkearifan ilahiah akan mampu mencapai tujuan ideal secara berkesinambungan dan bertahap dalam pergaulan dunia yang semakin terbuka dan global. Disinilah pendidikan Islam memiliki tanggung jawab moral dan berpeluang berperan aktif.

Kecerdasan dan keutuhan manusia beriman, berilmu, trampil, sehat dan ber- tanggungjawab adalah pokok-pokok tujuan pendidikan nasional (UUSPN No.2/1989: ps 4) yang lebih mungkin dicapai jika pendidikan keagamaan, keilmuan dan ketrampilan diletakkan sebagai kesatuan sistematis dan integral. Pendidikan agama (Islam) adalah muatan wajib seluruh jenis, jalur dan jenjang pendidikan (UUSPN: ps 39) yang perlu dikembangkan sebagaj dasar kesatuan keimanan, kecerdasan dan ketrampilan. Bahan dan penyajian pendidikan agama (Islam) disusun dalam kesatuan wawasan iptek semua mata pelajaran dan bidang studi serta ketrampilan.

Untuk itu pengembangan metodologi belajar mengajar harus menempatkan guru dan murid (peserta didik) sebagai pelaku utama pencapaian tujuan pendidikan Islam. Fungsi penting pendidikan dalam islam ialah sebagai usaha mengembangkan kemampuan manusia memenuhi kebutuhan hidupnya dan mengatur serta mengolah diri dan lingkungan hidupnya. Relevansi pendidikan islam ini dapat dikaji antara lain dalam pemikiran Ibn Khaldun dan Malik bin Nabi.

Konsep dan tujuan pendidikan Islam dikembangkan berdasarkan pengertian bahwa manusia adalah pembuat sejarah hidupnya sendiri. Untuk itu, fungsi wahyu perlu dipertegas bukan untuk kepentingan Tuhan, tetapi bagi seluruh kepentingan manusia memenuhi kebutuhan hidup, fungsi dan peran pembuat sejarah. Iptek bukan hanya bagian dari kebudayaan dan sejarah kehidupan manusia, tetapi penjabaran lebih lanjut dari fungsi sosiologis wahyu tersebut.

Dengan demikian maka, kebudayaan dan iptek adalah mata rantaj sejarah manusia dalam mencapai tujuan hidup. Selain itu, keduanya (kebudayaan dan iptek) adalah mata rantai sejarah dari realisasi keyakinan tauhid dan penundukan diri manusia kepada sunnatullah sebagaj suatu penyembahan kepada Penciptanya. Pendi- 
dikan Islam, tidak lain adalah jawaban atas problem-problem kebudayaan, iptek dan pencapaian tujuan hidup serta realisasi keyakinan tauhid, penundukan diri pada sunnatullah dalam alam sejarah tersebut.

Tujuan, sistem dan metodologi disusun dengan menempatkan sejarah sebagai bahan utama. Demikian pula realitas aktual tempat manusia hidup. Karena itu, pendidikan adalah satu titik dari mata rantai sejarah, bukan hanya mengenai bagaimana manusia bekerja, tapi mengenai bagaimana manusia membuat sejarah.

Pendidikan (Islam) tak hanya berkaitan dengan profesi, tetapi juga kecerdasan kreatif dan keteguhan pada cita-cita dan tujuan membuat sejarah. Kurikulum disusun bukan hanya sebagai media transfer nilai, kebudayaan dan iptek atau membuat manusia bisa makan. Kurikulum disusun sebagai upaya mengembangkan kemampuan merumuskan nilai, menemukan dan mengembangkan iptek sesuai dunia dan sejarahnya sendiri.

Kurikulum dalam pendidikan Islam, tak hanya berurusan dengan kemampuan kerja, tapi bagaimana membuat dan menyikapi pekerjaan. Demikian pula, bukan hanya persoalan bagaimana menyembah Tuhan, tetapi mengapa menyembah-Nya. Bukan hanya memahami nilai dan iptek yang ada, tetapi merumuskan nilai dan menemukan iptek.

Dengan demikian pendidikan Islam bukan hanya berurusan dengan persoalan memahami wahyu tekstual (Al Quran) dan sunnah, bertindak berdasar pemahaman atas wahyu AI Quran dan sunnah tersebut. Tetapi juga berurusan dengan persoalan memahami dan mengungkap rahasia wahyu aktual dalam realitas alam dan realitas sosial-humaniora serta sejarah. Inilah sunnatullah atau hukum-hukum Tuhan yang petunjuk dasarnya terdapat dalam AI Quran sebagai wahyu tekstual dan sunnah Rasul.
Pengembangan pendidikan Islam di Indonesia, perlu menjadikan realitas kebangsaan dan pendidikan nasional sebagai bahan acuan. Dalam sistem pendidikan nasional, pendidikan (agama) Islam harus memenuhi fung'sinya sebagai dasar moral dan nilai serta sebagai dasar ontologis seluruh unsur pendidikan dan seluruh bidang studi di semua jalur, jenis dan jenjang pendidikan baik sekolah atau pun madrasah. Posisi pendidikan agama sebagai kurikulum wajib bagi semua jenis, jalur dan jenjang pendidikan dalam sistem pendidikan nasional perlu dikembangkan sesuai fungsinya tersebut.

Untuk maksud itulah, persoalan kesatuan semua bidang ilmu (iptek) dan ilmu yang disebut ilmu agama, perlu diperjelas. Persoalan ini tidak hanya mengenai dikotomi ilmu, tetapi apa yang menjadi dasar kesatuan semua ilmu (iptek). Demikian pula kesatuan antara iman dengan ilmu, bekerja memenuhi kebutuhan hidup dan kegiatan ibadah serta dalam membuat sejarah.

Studi kealaman dan studi sosial-humàniora adalah mata rantai dari keimanan. Pendidikan tauhid bukan hanya studi tentang nama Tuhan, tetapi juga studi tentang hasil karya Tuhan dalam realitas alam dan sosial-humaniora. Ketakwaan dan keinsankamil-an bukan hanya masalah ritual transendental, tetapi juga meliputi ritual sosial dan ritual natural.

Persoalannya ialah bagaimana dalam setiap episod ritual itu terangkai dalam mata rantai kesatuan realitas. Dengan demikian, studi kealaman akan terarah pada penyadaran mengenai seluruh realitas yaitu manusia dan Tuhan. Demikian pula sèbaliknya studi mengenai wahyu Tühan yang verbal juga terangkai dalam mata rantai kesatuannya dengan sunnatullah dalam realitas alam dan sosial-humaniora. Pendidikan Islam harus mampu menjelaskan kesatuan semua realitas baik dalam bentuk 
Topik: Pendidikan Islam dalam GBHN dan Realitas Kebangsaan, Abdul Munir Mulkhan

kesatuan hirarchis dan kesatuan vertikal seluruh realitas dan seluruh bentuk ritual tersebut.

Secara pragmatis, pendidikan Islam meliputi dimensi iman, ibadah dan akhlaq. Dimensi iman bukan hanya soal nama Tuhan, tapi meliputi studi fisika, biologi dan sosial-humaniora. Dengan itu nama Tuhan terbaca dalam realitas alam dan sosial-humaniora. Ibadah bukan hanya penyembahan kepada Tuhan tapi juga sebagai pekerja profesional. Akhlaq bukan hanya berkaitan dengan persoalan bagaimana berbuat baik pada orang-tua dan bersikap pada Tuhan, tetapi kepedulian terhadap lingkungan alam dan sosial.

\section{Kesatuan Iman, Iptek dan Kemanusiaan}

Semua penganut agama, percaya dan mengimani bahwa Tuhan adalah Pencipta alam dan kehidupan manusia. Persoalan mulai muncul ketika manusia mengembangkan pemikiran yang menjadikan alam dan kehidupan manusia sebagai objek kajian secara induktif. Pada saat yang sama juga dikembangkan pemikiran yang menjadikan teks wahyu Tuhan sebagai objek kajian secara deduktif. Dalam perkembangan lebih lanjut, hasil kedua sistem pemikiran tersebut dipandang saling tak terkait bahkan bertentangan.

Sementara manusia menjadi subjek kedua sistem pemikiran itu, penganut agama berbeda pendapat dalam memandang posisi dan fungsi iptek bagi keimanan dan kemanusiaan. Muncullah persoalan iptek bebas nilai yang melahirkan perbedaan pendapat antar agamawan dan di antara mereka dengan ilmuwan, bahkan dalam komunitas pemeluk suatu agama. Hingga sekarang, persoalan tersebut belum menemukan penyelesaian yang memuaskan semua pihak. Keimanan kemudian ti- dak diperlakukan sebagai wacana kemanusiaan yang dinamis. Sebaliknya, iptek tidak ditempatkan sebagai wacana keimanan.

Persoalan iptek bebas nilai, akhir-akhir ini marak kembali ketika muncul gagasan pelahiran manusia melalui rekayasa iptek dalam cloning. Sintesis kedua pandangan ini terletak pada wilayah praksis bahwa pada akhirnya kegiatan iptek merupakan human service. Hal ini dapat dilihat dari tulisan Sudaryono dalam harian Kompas (9 Mei 1997) yang mencoba memadukan pandangan Liek Wilardjo (tidak bebas nilai) dan Th. Sumartana (bebas nilai).

Di luar perdebatan iptek bebas nilai dan perpaduannya, setiap ilmuwan sadar sepenuhnya bahwa manusia adalah subjek iptek, dan seluruh ragam realitas sebagai objek. Suatu saat, teknologi bisa teriepas dari keterlibatan manusia, namun manusia tetap menjadi pemaın utama. Hingga tahap praksis sekalipun, manusia menjadi pelaku dan pemanfaat teknologi. Karena itu, nilai adalah problem manusia subjek dan pelaku iptek, bukan problem iptek itu sendiri.

Persoalan itu dapat dijernihkan dengan meletakkan iptek dalam dinamika historis kemanusiaan dan realitas alam, sosialhumaniora dan metafisis sebagai basıs ontologis iptek. Seluruh realitas itu tidak memiliki nilai intrinsik, kecuali penilaian manusia sebagai bukti peran aktifnya. Agama pun menjadi bernilai ketika manusia melibatkan diri dan bukan karena Tuhan memberi nilai. Melalui cara semacam itu mungkin kita bisa membayangkan suatu kesatuan antara nilai moral, etik dan keagamaan (iman) dengan iptek.

Problem etik dalam kasus cloning manusia, bukanlah iptek, tapi kemanusiaan itu sendiri. Kelahiran dua manusia atau lebih yang identik melalui rekayasa cloning non-sexual, bukanlah kisah manusia mela- 
wan taqdir tetapi problem konsep taqdir itu sendiri. Teknik cloning, telah membuat agamawan khawatir akan kelahiran banyak manusia yang kualitas kriminalnya identik. Namun, juga bisa lahir banyak manusia yang mempunyai kualitas iman dan etik yang seperti pendeta atau ulama dengan kualitas fisis tinggi.

Kekhawatiran agamawan tersebut telah menyebabkan jalan simpang "agama" atau iman dan "ilmu" atau iptek semakin terbuka lebar dan bercabang sangat rumit, hingga hampir mustahil dipetakan secara jelas. Tetapi sejarah mencatat kemajuan iptek secara luar biasa yang tidak tertandingi oleh karya agamawan atau ulama. Dengan penuh percaya diri, para ilmuwan melepaskan diri dari dominasi lembaga keagamaan, agamawan dan ulama. Tetapi ilmuwan menjadi tertuduh telah keluar dari batas-batas moral dan etik yang hanya ditafsirkan secara sepihak oleh elit agamawan tanpa mendengar persepsi moral dan etik teknolog dan ilmuwan.

Sejarah terus mencatat pertempuran yang tak pernah berakhir antara baik dan buruk, benar dan salah. Hanya dalam mitos, yang baik dan benar seperti tafsir agamawan itu selalu menang. Namun, apa yang diangggap buruk dan salah itu justru terus maju tanpa bisa dibendung, sehingga konsep kebaikan dan kebenaran menghadapi krisis historis. Sementara di sisi lain para kriminal terus ber-reingkarnasi menjadi semakin perkasa.

Sepanjang penafsiran kebaikan dan kebenaran sepihak menurut ulama dan agamawan, sejarah akan mencatat kembali kekalahan kebaikan dengan lahirnya "manusia cloning" dalam waktu yang tak terlalu lama. Ketika teknolog selalu menjadi pemenàng, sejarah juga mencatat kebangkrutan kémanusiaan dan lahirnya masyarakat yang menderita sakit seperti analisis Erich Fromm. Persoalannya adalah bagaimana kemajuan iptek justru semakin membuat kehidupan manusia menjadi semakin sejahtera dan penuh kedamaian. Kekuasaan penuh keadilan dan kearifan seperti fokus dakwah berbagai agama.

Persoalan di atas menunjuk kesatuan sistematis dan fungsional iptek dengan keimanan terhadap kebenaran wahyu. Dengan demikian, kebenaran wahyu bukan sekedar dasar etik iptek, tetapi justru sebagai wacana iptek itu sendiri. Agama dengan keyakinan atas kebenaran wahyu, tak hanya berbicara mengenai Masjid atau Gereja, keranda atau kematian, tetapi juga berbicara mengenai konstruksi jembatan, mekanisme pasar, pabrik dan teknologi gambut.

Kemakmuran ekonomi dan kemajuan iptek, memang bukan jaminan suatu bangsa bebas dari krisis kemanusiaan. Kasus bunuh diri massal sekte Pintu Surga (Heaven's Gate) di California baru-baru ini dan sebelumnya, adalah resiko kemakmuran tanpa etika dan kekayaan batin keagamaan. Jika demikian, manusia tidak hanya terasing dari dirinya sendiri dan benda ciptaannya, tetapi juga dari Tuhan. Sebaliknya, masyarakat beriman pun gagal membebaskan diri dari derita kemiskinan dan konflik yang tak jarang atas nama keimanan telah dengan sengaja membasmi manusia sesamanya.

Karena itu, mungkin perlu dikembangkan suatu kesadaran bahwa ilmu mengenai Tuhan dan ciptaan-Nya adalah dasar seseorang untuk mengimani dan mempercayai Tuhan dan kebenaran wahyu-Nya. Dengan demikian, keyakinan terhadap kebenaran wahyu Tuhan dan agama-Nya adalah langkah kedua sesudah orang memperoleh ilmu mengenai Tuhan dan ciptaan-Nya. Tanpa ilmu tentang Tuhan dan ciptaan-Nya, sulit dibayangkan seseorang menjadi beriman kepada-Nya. 
Topik: Pendidikan Islam dalam GBHN dan Realitas Kebangsaan, Abdul Munir Mulkhan

Semua pemeluk agama apa pun meyakini bahwa Tuhan itu Pencipta seluruh ragam realitas yang menjadi basis ontologis iptek. Hal ini berarti bahwa iptek adalah cara manusia memberi makna, nilai dan fungsi seluruh ciptaan Tuhan. Melalui iptek, manusia memahami realitas ciptaan Tuhan dan melalui pemahaman itu manusia memahami keberadaan dan ke-Maha Kuasaan Tuhan itu sendiri.

Hubungan iptek dengan keberimanan, menunjuk hubungan manusia sebagai subjek iptek di satu pihak dan realitas ciptaan Tuhan yaitu alam dan sosial-humaniora sebagai objek iptek. Pada tahap lanjut, iptek sendiri merupakan objek (untuk membedakan objek materia dan forma) pemahaman dari subjek manusia itu sendiri. Kebebasan nilai atau sebaliknya, bukanlah persoalan iptek, tetapi persoalan manusia dalam posisinya sebagai subjek iptek tersebut.

Seluruh masalah iptek adalah persoalan manusia sebagai pelaku iman dan etik. Siapa yang harus beriman dan berlaku etik, kecuali manusia dan bukan realitas alam dan sosial-humaniora atau iptek sebagai objek. Pola hubungan sistematis Tuhan sebagai Pencipta, manusia, realitas alam dan sosial-humaniora tetap menempatkan manusia sebagai subjek penilai dan pelaku kreatif. Demikian pula hubungan subjek-objek iptek serta hubungan jptek dan manusia dalam posisi sebagai subjek iptek itu sendiri.

Penjernihan kesatuan sistematis dan fungsional semua realitas dengan Tuhan sebagai Pencipta akan menunjuk kesatuan subjek-objek iptek, manusia-iptek serta iptek dengan keberimanan dan etika yang serupa. Dengan demikian dapat dimengerti adanya hubungan sistematis dan fungsional dari semua ragam iptek termasuk ilmu mengenai ketuhanan atau tauhid. Keimanan berhubungan sistematis dan fungsional de- ngan ilmu kealaman dan ilmu sosial-humaniora yang meletakkan manusia sebagai pelaku utama dan kreatif.

Jika kita sepakat bahwa realitas metafisis sebagai wacana ketuhanan lebih bernilai daripada realitas sosial-humaniora dan alam, maka ilmu mengenai ketuhanan berada pada posisi tertinggi. Namun, manusia lebih bisa memahami realitas metafisis ketuhanan melalui tahapan ilmu kealaman dan sosial-humaniora. Karena itu, seluruh iptek dan iman serta kemanusiaan dapat diletakkan dalam suatu kesatuan kontinum yang sistematis dan fungsional.

Melalui cara itu, manusia dapat menilai setiap tahapan iptek sebagai mata rantai. Persoalannya bukanlah iptek itu bebas nilai, tetapi bagaimana manusia memberi nilai iptek, realitas alam dan sosial-humaniora. Dari sini manusia bisa berbicara tentang apa yang baik dan buruk bagi iptek dan dirinya sendiri. Karena itu, tidak ada yang lebih bermoral antara ilmuwan, teknolog, ulama atau agamawan, selama mereka menyadari kesatuan sistematis dan fungsional antara manusia, iptek, realitas dan Tuhan.

\section{Kesatuan Realitas, Iptek dan Sunnatullah}

Pengembangan konsep dan strategi pendidikan Islam diperlukan untuk memberi arah pengembangan iptek sebagai bukti yang semakin memperkokoh keyakinan tauhid. Pencapaian tujuan dan realisasi fungsi pendidikan Islam tersebut ditentukan wawasan etik kesatuan iptek-tauhid dan kesatuan sistemik pendidikan Islam dan seluruh proses belajar mengajar di seluruh jenjang sekolah atau madrasah.

Karena itu, pendidikan Islam perlu dikembangkan dengan tiga sasaran. Pertama, memenuhi fungsi akademik menumbuhkan wawasan tauhid dalam iptek. Ke- 
Topik: Pendidikan Islam dalam GBHN dan Realitas Kebangsaan, Abdul Munir Mulkhan

dua; pengembangan iptek sebagai fungsi keyakinan tauhid dan sebaliknya pengembangan keyakinan tauhid melalui pengembangan iptek. Ketiga, pengembangan kemampuan profesional dan ketrampilan beribadah dan bekerja sebagai bagian integral kegiatan ibadah.

Keyakinan tauhid dikembangkan dalam wacana iptek, sehingga pengembangan dan aplikasi iptek adalah tauhid aktual. Pengembangan kemampuan profesional beribadah dan bekerja diarahkan menumbuhkan kehidupan manusia dalam masyarakat yang sejahtera, berkemakmuran ekonomi dan berkemajuan teknologi. Pendidikan Islam dikelola berdasar kesatuan wawasan dan kesatuan etik iptek- tauhid. Untuk itu, ilmu keagamaan sebagai bahan dasar pendidikan Islam dikembangkan dan disajikan sebagai wacana keilmuan (iptek).

Namun, fungsi strategis proses belajar mengajar yang dikelola tenaga pengajar (dosen atau guru), mengharuskan pendidikan yang menghasilkan tenaga didik dengan kualifikasi tersebut. IAIN dan fakultas agama atau pendidikan di perguruan tinggi Islam, perlu dikembangkan sehingga dapat melahirkan tenaga pengajar sesuai kebutuhan itu. Tanpa upaya konseptual ini, tenaga pendidik agama Islam hanya akan memenuhi kebutuhan ideologis daripada fungsi yang lebih obyektif memenuhi kebutuhan manusia dan pengembangan iptek sebagai realisasi keyakinan tauhid.

Kemajuan iptek memang mempertinggi kemakmuran ekonomi dunia, namun belum menyelesaikan problem kemanusiaan. $\dot{S} e-$ baliknya, fungsi agama, tak dapat dipenuhi hanya sebagai dasar etik iptek, tetapi harus bisa menunjukkan bukti-bukti empiris resiko kemanusiaan di masa depan. Tidak hanya meminta dunia modern merujuk wahyu yang tak mereka imani, tapi menunjukkan kebenaran wahyu dengan bukti-bukti ilmiah. Atau, kebenaran ilmiah harus meru- pakan tahap pencapaian kesadaran ilahi (tauhid).

Agama bukanlah sekedar dasar etik iptek, tapi wacana iptek itu sendiri. Pemisahan keduanya telah menyebabkan keterasingan manusia menjadi berganda yaitu terasing dari dirinya sendiri dan benda ciptaannya serta terasing dari Tuhannya. Jika demikian, bangsa berkemakmuran ekonomi dan berkemajuan teknologi tanpa kearifan ilahi, akan menghadapi krisis kemanusiaan dan peradaban serius. Namun, umat beriman terus dilanda kemiskinan dan terkebelakang akibat iman diletakkan di luar wacana iptek.

Keyakinan iman, tumbuh dari kajian ilmiah dan hanya mereka yang mengetahui dan mengenal Tuhan dengan ciptaan-Nya, keyakinan tauhid dan ibadahnya akan semakin kukuh. Wahyu harus ditafsirkan dalam wacana iptek dan sebaliknya. "Agama" tidak diartikan di luar wacana iptek, tetapi keduanya diletakkan dalam kesatuan wawasan, etik dan sistematis. Seluruh ilmu keagamaan seperti figh, kalam, tafsir dan lainnya harus difahami sebagai bagian sistematis dan integral wacana iptek, sehingga hukum keilmuan berlaku atasnya seperti hukum keilmuan iptek dan sebaliknya.

Keyakinan tauhid akan tumbuh sesudah manusia memperoleh ilmu mengenai Tuhan dan'seluruh ciptaan-Nya, sehingga keyakinan tauhid berakar pada iptek. Hal ini bersumber dari kesatuan hirarchis alam dan sosial-humaniora dengan realitas metafisis (gaib). Kesatuan ini menunjukkan kesatuan sistematis sunnatullah dengan teks verbal AI Quran dan Sunnah.

Karena itu, ilmu (baca: iptek) adalah awal dari iman (baca: Imtak) seperti terlihat dalam lima ayat surat lqra' dan sikap Màlaikat ketika Tuhan mencipta manusia (Adam). Untuk itu, konsep kesatuan ilmu dan realitas hampir seluruh filsuf muslim perlu dijadikan referensi (lihat Nasr dalam 
Topik: Pendidikan Islam dalam GBHN dan Realitas Kebangsaan, Abdul Munir Mulkhan

Hirarhi IImu, Osman Bakar, Mizan, 1997) kesatuan etik Iptek dan Imtak. Demikian pula paralelisme ilmu kealaman dan sosialhumaniora dengan ilmu keagamaan (Rahman, litihad, Pustaka, 1984).

Kesatuan itu juga terlihat dari ilmu mengenai realitas dan alat mengetahui (metodologi). Fenomena kesatuan juga dalam tiga tingkat kesadaran; iman, kemanusiaan dan sosial (Mutahhari, Masyarakat dan Sejarah; Kritik Islam atas Marxisme dan Teori lainnya, Mizan, 1986). Demikian pula hubungan reflektif amal shaleh dan keyakinan atas sifat Tuhan (Izutsu, Konsep-Konsep Etika Religius dalam Qur'an, Tiara Wacana, 1993). Dan kemajuan metafisis kesadaran diri dalam refleksi sosial (Sardar, Sains, Teknologi dan Pembangunan Di Dunia Islam, Pustaka, 1989).

Dalam analisa kontemporer, hirarhi fungsional realitas dalam analisis Schumacher (Keluar Dari Kemelut, LP3ES, 1981) dapat menjadi bahan kajian mengenai kesatuan keyakinan tauhid (realitas metafisis/ gaib) dengan pengetahuan kealaman dan sosial-humaniora. Juga hubungan kecerdasan emosional (fisik) dan kecerdasan emosional (pengendalian nafsu/ metafisis) (Goleman, Emotional Intelligence, Gramedia, 1996) menjadi bahan kajian kesatuan sistematis tingkat-tingkat kemampuan mencapai kesadaran ilahiah.

\section{Otoritas Ilmu dalam Perspektif Hukum Tuhan'}

Kajian atas persoalan pendidikan Islam. khususnya pendidikan agama Islam yaitu pendidikan islam di sekolah (pendidikan umum), sering hanya menyentuh kulit tanpa substansi. Akar persoalan pendidikan Islam ini berkaitan dengan fungsi paradigmatik tujuan holistik, terutama jika dilihat dari wawasan sistemik Pendidikan
Nasional. Hal ini semakin jelas dalam fungsi pendidikan Islam sebagai kurikulum wajib semua jenis, jalur dan jenjang pendidikan bagi pendidikan agama (|siam) (ps| 39 ayat 2 , UUSPN/2/89).

Dalam hubungan itulah pengembangan kurikulum dan metodologi pendidikan agama Islam dapat dilakukan melalui problematisasi Freire (Pendidikan Kaum Tertindas, LP3ES, 1985; Pendidikan Sebagai Praktek Pembebasan, Gramedia, 1984). Hal ini menjadi semakin mendesak dalam perkembangan masyarakat yang semakin menjadikan iptek sebagai pemandu utama. Sementara pada saat yang sama wawasan keagamaan Islam masih dibayangi sikap ideologis menolak peran iptek dalam pengembangan keyakinan tauhid.

Sejak dekade terakhir jalan simpang "agama" dan "ilmu" makin terbuka lebar dan bercabang sangat rumit, hingga hampir mustahil dipetakan dengan jelas. Teknik cloning mulai merambah manusia sesudah tumbuhan dan binatang, berakibat tergugatnya sainstis oleh ulama (baca ilmuwan keagamaan). Tuduhan bahwa teknik cloning melanggar prinsip etik dan moral, hanya sepihak menurut persepsi ulama tanpa mendengar persepsi moral dan etik para saintis.

Hukum Tuhan ditafsirkan sepihak sebagai syari'ah dalam figh menolak firman

\footnotetext{
'Pernah disampaikan dalam Stadium General; Aplikasi cloning sebagai Rekayasa sains dan Teknologi serta Tantangannya Bagi Umat Islam oleh Forum Pengkajian Hukum Islam (FPHI) jurusan Syariah UMS, 1 Mei 1997 dengan judul yang sama. Sebagai isi makalah ini juga pernah disampaikan dalam acara Semiloka Penulisan Buku Teks Pendidikan Agama Islam Bernuansa Iptik oleh F Tarbiyah IAIN Sunan Kalijaga Yogyakarta, tanggal 15 - 17 April 1997.
} 
Topik: Pendidikan Islam dalam GBHN dan Realitas Kebangsaan, Abdul Munir Mulkhan

yang menyatakan realitas alam dan sosialhumaniora pertanda kehadiran dan kebenaran ilahiah. Ahli ilmu keagamaan mengklaim diri paling dekat Tuhan dan paling berhak menafsirkan firman. Ini adalah bias ilmu keagamaan yang memperoleh kekuatan politik'dengan memihak kekuasaan sebagai tempat berlindung. Hal ini menyebabkan semua pihak yang berbeda pendapat dicap sebagai tak bermoral, salah dan tidak berakhlaq.

Namun, sejarah terus mencatat pertempuran yang tak pernah berakhir antara baik dan buruk, benar dan salah. Al Quran sendiri melukiskan drama pertempuran itu sejak manusia diciptakan. Bahkan malaikat pun "protes keras" ketika Tuhan bermaksud menjadikan makhluk bernama manusia. Karena itu, fungsi agama (Al Quran) bagi kehidupan sejarah, tampaknya perlu dikoreksi ulang.

Konsep malaikat yang tak berkehendak, perlu penjernihan. Juga fungsi agama (Al Quran) yang meniadakan keniscayaan perubahan sejarah sesudah diturunkan. Hal ini sering menjadi pelindung dan tempat lari umat beragama ketika gagal melawan ketidakadilan, keburukan dan kemiskinan dirinya. "Kesadaran jabariyah" ini terlembaga dalam sistem teologi yang menjadikan sejarah sebagai kreasi Tuhan dan bukan sebagai medan peran kreatif manusia.

Akibatnya, Al Quran kehilangan fungsi profetiknya dan hanya pernah berlaku. Sistem kebenaran dimonopoli masa lalu yang tak pernah bisa diulang. Manusia menjadi ditindas oleh elit atas nama kebenaran agama dan Tuhan. IImu keagamaan; kalam. figh dan tafsir mengalami bias sebagai kreasi Tuhan daripada hasil daya kreatif sejarah dan manusia. Para ilmuwan keagamaan dan pendidikan tinggi Islam berhenti mencari dan memahami makna fungsional Al Quran hanya karena takut dihukum Tuhan dan takut berbeda dengan ulama masa lalu.
Pendidikan dan dakwah berubah dari fungsi pembelajaran menjadi indoktrinasi kelas elit keagamaan.

Angapan ilmu keagamaan lebih bermoral daripada kealaman dan sosial-humaniora. Saintis dianggap tidak berakhlaq dibandingkan ulama (ilmuwan keagamaan) adalah cermin kesombongan atas nama Tuhan. IImu keagamaan dianggap benar hanya karena bersumber teks wahyu dan ilmu kealaman dan sosial-humaniora dianggap salah hanya karena bersumber realitas aktual. IImuwan keagamaan merasa lebih berhak memperoleh surga dan dekat Tuhan dan saintis ditempatkan jauh di luar wilayah surgawi. Namun, ulama selalu gagal menikmati keramahtamahan Tuhan dan mengalami kemiskinan dan ketidakadilan.

Akibatnya, wacana ilmu dan kebudayaan kehilangan fungsi dan terbelenggu tirai kepalsuan keagamaan dan legitimasi penindasan sejarah atas nama Al Quran yang tak pernah disentuh kecuali apa menurut ulama. Kesadaran keagamaan dibangun di atas mitos bahwa yang baik dan benar selalu menang. Namun, mitos itu selalu gagal menghancurkan konsep buruk dan salah yang sering tampil lebih awal. ketika yang baik dan benar hampir selalu datang terlambat.

Problem eksistensial itu lebih transparan dalam pendidikan, khususnya pendidikan Islam yang menganggap diri paling bermoral dan benar. Pendidikan Islam sering hanya berhasil menyentuh sisi luar persoalan akibat terperangkap menjadi wacana ideologis dan teologis, bukan sebagai wacana peradaban atau kebudayaan dan di luar wilayah otoritas manusia. Manusia pun mudah menghindar dari tanggung jawab sejarah dengan mengundang kehadiran Tuhan dalam menyelesaikan berbagai persoalan hidupnya. 
Kita pun perlu bertanya, apakah syari'ah dan agama seperti dimaksud Al Quran dan Tuhan hanya melibatkan sebagian wilayah kehidupan manusia. Agama, jika terma ini dimaksud syari'ah Tuhan, seharusnya meliputi; wacana kemanusiaan dan keduniawian sebagai realitas terbuka dari semua kemungkinan perubahan. Karena itu, terma ilmu keagamaan perlu dikoreksi tak hanya meliputi bidang yang selama ini terlembaga dalam fakultas agama.

Jika ilmu keagamaan adalah pencarian dan pemahaman Tuhan dan hukum ciptaanNya (sunnatullah), ia meliputi dimensi ketuhanan dan wahyu tekstual, tapi juga kealaman, sosial-humaniora dan rekayasa atas nama keduanya. Dengan cara ini kita baru bisa mendiskusikan perkembangan sains dan teknologi genetika dan biologis cloning manusia yang kini mengguncang altar gereja dan mimbar-mimbar masjid. Atau, kita gagal berlaku adil. Kita tolak ilmu kealaman dan sosial-humaniora sebagai ilmu agama tapi gelisah ketika ia dianggap melanggar nilai moral yang hanya mendengar khutbah tapi gagal mendengar hasil seminar dan penelitian empiris.

Wahyu tekstual justru dengan jelas menyatakan kesepadanan dengan realitas kealaman dan sosial-humaniora. Sunnatullah sebagai wahyi aktual dalam realitas kealaman dan sosial-humaniora berada dalam posisi sejajar sebagai penjelas wahyu tekstual. Penelitian atas sunnatullah (alam dan sosial-humaniora) menjadi data empiris dan awal pemahaman ketuhanan (tauhid). Wahyu AI Quran menjadi sulit dijelaskan dan dimengerti tanpa data penelitian empiris ketuhanan dalam realitas kealaman dan sosial-humaniora.

\section{Posisi Etika dan Agama dalam Iptek}

Bias ilmu keagamaan itu kini menyebabkan dunia pendidikan Islam terutama fiqh dan kalam menghadapi dekonstruksi dan krisis serius setelah spekulasi cloning. Dikhawatirkan terjadi pembiakan penjahat sebagai imperium kriminal, menguasai sejarah kehidupan. Namun, sikap ini menunjukkan ketakberdayaan ahli ilmu keagamaan mengembangkan kehidupan yang lebih manusiawi. Kita tidak berani memprediksi kemungkinan lahirnya manusia cloning ulama, hukama dan filsuf yang arif dan bijaksana.

Sementara teknologi cangkok organ tubuh justru bisa mencipta manusia kliping sebagai akumulasi semua unsur kebaikan banyak orang. Dapat dibayangkan lahirnya manusia yang berotak Einstein, jantung Maradona, tubuh militer, postur Sharon Stone dan hatinya ulama. Dengan demikian manusia masa depan memiliki fisik tangguh, otak cerdas, jantung super, tapi arifbijaksana, adil dan jujur.

Selain cloning, dunia masih akan dikejutkan oleh teknologi mesin waktu (Stephen Hawking, Riwayat Sang Kala, Grafiti, 1994; Black Holes And Baby Universes, Gramedia, 1995). Dengan alat itu, manusia akan melancong jauh ke masa lampau merubah sejarah. Atau melancong jauh ke masa depan ke surga, neraka, hari Makhsyar, dan Lauhil mahfudz. Seluruh doktrin kalam harus ditinjau ulang.

Jika dengan cloning, ilmu fiqh kehilangan fungsi, dengan mesin waktu doktrin aqidah harus diubah. Spekulasi ini memberikan inspirasi pemikiran imajinatif dalam sejumlah film fiksi. Namun, kita juga bisa membayangkan manusia yang semakin arif, bijaksana dan adil ketika manusia melihat realitas masa depan akhirat dan bertandang ke Lauhil mahfudz. Manusia menjadi sadar mengenai makna kehidupan duniawi, sehingga membenarkan dan menundukkan dalam Islam. Namun untuk itu ahli ilmu keagamaan (Al Quran) harus bisa meyakinkan saintis dana peradaban mo- 
dern melalui penelitian empiris, bagaimana akhir dari pelanggaran terhadap hukum Tuhan (sunnatullah) atau hukum kauniah.

Keyakinan atas keramahtamahan islam terhadap kehidupan, tidak cukup hanya menolak sains dan menyatakan kebenaran wahyu tekstual yang memang tidak mereka imani. Persoalannya bagaimana meyakinkan dunia modern dan saintis menurut logika teknologi dan membuktikan dalam kehidupan empiris ketercukupan pemenuhan hidup duniawi ini menurut pedoman Al Quran.

Tanpa upaya itu, mitos kebaikan dan kebenaran yang selalu menang akan terus krisis historis. Sementara para kriminal pun terus ber-reingkarnasi menjadi semakin perkasa. Namun, mitos ini bisa memberi inspirasi optimisme dimana sesudah melihat neraka melalui mesin waktu orang lebih percaya atas kebenaran wahyu.

Di sisi lain, sejarah juga menunjukkan kalahnya agamawan bersaing dengan saintis. Penolakan keras kaum agamawan terhadap cloning akan bernasib sama. Ketika saintis selalu menjadi pemenang, sejarah juga menjadi bukti teknologisme melahirkan masyarakat sekarat seperti analisis Erich Fromm (Masyarakat Sehat, Obor, 1995).

Peradaban teknologis dan industrial memang mulai butuh agama. Namun cendekiawan muslim harus bisa meyakinkan resiko masa depan yang akan mereka hadapi jika manusia hanya dipandu oleh penemuan iptek. Tidak hanya meminta dunia modern merujuk wahyu yang tidak dipercayai, tapi menunjukkan bukti data empiris yang disajikan sesuai logika saintis dan teknologis.

Karena itu, agama bukan sekedar dasar etik ilmu yang selalu menjadi kelas kedua. Agama adalah wacana keilmuan itu sendiri. Agamawan adalah saintis seperti Al Kandi, filsuf yang fisikawan, Ibnu Sina ahli medik, Al Ghazali ahli matematika. Agama bukan hanya masalah masjid dan keranda, tapi jembatan, pasar, pabrik dan teknologi gambut, sehingga umat bisa membangun masjid yang indah dan bersih dengan jama'ah yang sehat dan sejahtera.

Seperti telah dikemukakan, kemakmuran ekonomi dan kemajuan teknologi bukaniah jaminan suatu bangsa bebas krisis kemanusiaan. Kasus bunuh diri massal sekte Pintu Surga (Heaven's Gate) di California baru-baru ini dan sebelumnya, adalah resiko kemakmuran tanpa kekayaan batin yang hanya ada dalam agama. Manusia modern tidak hanya terasing dari dirinya sendiri dan benda ciptaannya, tetapi juga dari Tuhan.

Di sisi lain, masyarakat berıman pun dilanda kemiskinan dan terkebelakang akibat iman diletakkan di Iuar sains. Tanpa meletakkan posisi iman dan sains (ilmu) dalam satu garis kontinum, peradaban industrial akan sampai batas akhir gagal menyelamatkan diri. Dan agama pun sampai batas kritis tak mampu memberi jalan keluar penderitaan. Kita tidak belajar hidup. tapi belajar bunuh diri dan secara sadar menggali liang kubur.

\section{Kesatuan Problem Iptek dan Pendidikan Islam}

Berbagai persoalan keilmuan di atas, menjadi lebih struktural dan kultural ketika bias ilmu keagamaan menjadi dasar pelembagaan pendidikan (Islam) dan pengembangan kehidupan sosial Islam. Perlu disadari bahwa mengimani wahyu, belum menjamin kesalehan. Keyakinan iman masih memerlukan pencarian makna yang tersembunyi dari sunnatullah dalam kehidupan alam dan sosial-humaniora. Kemakmuran dan kemajuan Iptek memang bisa tanpa iman. namun sering menyimpang dari tujuan. Sebaliknya, tanpa iptek, keya- 
Topik: Pendidikan Islam dalam GBHN dan Realitas Kebangsaan, Abdul Munir Mulkhan

kinan iman akan mudah luntur dan kebutuhan hidup sulit terpenuhi.

Karena itu, kritik konsep dan metodologi adalah akar persoalan pendidikan khususnya pendidikan Islam termasuk apa yang dikenal sebagai pendidikan agama Islam. Persoalan pendidikan Islam, bukanlah sekedar jumlah jam, tapi penerjemahan nilai wahyu sebagai wacana ilmu. "Agama" tidak diartikan di luar wacana ilmu, tetapi keduanya diletakkan dalam wacana kesatuan sistematis.

Selama ini, seluruh ilmu keagamaan seperti figh, kalam, tafsir dan lainnya dianggap identik dengan agama atau wahyu, sehingga berada di luar problem ilmu. Sikap ini meluas memasuki wacana pendidikan Islam, sehingga tidak jelas apakah pendidikan Islam merupakan problem ilmu dan wacana kemanusiaan atau ia merupakan hidayah sebagai peran langsung Tuhan.

Hal tersebut mengakibatkan kewenangan pendidikan Islam dalam mencapai tujuan ketakwaan pun tidak jelas. Konsep tujuan pendidikan Islam seperti itu sebenarnya lebih tepat sebagai paradigma untuk merumuskan tujuan yang lebih teoritis. Namun kajian mengenai masalah ini pun tidak banyak dilakukan, karena anggapan sudah jelasnya tujuan itu dalam petunjuk Al Quran. Karena itu harus dipertegas bahwa pendidikan (Islam) adalah masalah ilmu dan masalah kewenangan manusia untuk mendidik.

Jika ketakwaan seseorang adalah hak ketuhanan (hidayah), maka pendidikan tidak memiliki wewenang apa pun. Dengan demikian pendidikan hanya akan berfungsi sebagai pencari hidayah yang tak dapat dikonsep dan direncanakan. Menjadikan pendidikan sebagai upaya menumbuhkan ketakwaan seseorang akan bertentangan dengan kesadaran teologis hidayah itu sendiri. Disinilah konsep dan metodologi pendidikan harus dijernihkan dan dikonsep ulang.
Pendidikan harus tegas diletakkan sebagai problem kèmanusiaan dimana manusia memiliki kewenangan teoritis menghasilkan perilaku ketakwaan peserta didik. Konsep ketakwaan dalam pendidikan harus dilihat sebagai karya kemanusiaan dalam wujud perilaku empiris yang dapat dievaluasi. Dengan demikian evaluasi menjadi mungkin dilakukan terhadap peserta didik. Karena itu, konsep hidayah perlu dikembangkan sebagai tahap akhir yang lebih mungkin dapat dicapai sesudah seseorang mengikuti pendidikan.

Konsep tujuan ketakwaan, insan kamil atau kepribadian muslim perlu diterjemahkan dalam rumusan yang lebih teoritis dan empiris yang berkaitan dengan pengalaman kebertuhanan. Dari konsep inilah dapat disusun kurikulum, metodologi, proses belajar mengajar dan sistem evaluasi. Taksonomi kognisi, afeksi dan psikomotor Bloom dan Krathwohl (Nasution, Teknologi Pendidikan, Jemmars, 1982) mungkin dapat dipergunakan untuk merancang kurikulum dan berbagai model pengelolaan pendidikan Islam tersebut.

Jika tauhid adalah dasar ketakwaan, dan pendidikan Islam adalah problem kemanusiaan (bukan hidayah), maka problem pendidikan Islam akan berakar pada problem ilmu. Pengetahuan (baca; iptek) mengenai Tuhan dan pengalaman berketuhahan adalah akar keyakinan tauhid. Orang yang tak mengenal Tuhan dan berpengalaman berketuhanan keyakinannya terhadap Tuhan akan mudah goyah. Pendidikan islam harus merupakan upaya untuk memperkaya pengalaman kebertuhanan dan bahkan menemukan bukti kekuasaan Tuhan dalam realitas alam dan sosial-humaniora ciptaan-Nya.

Persoalannya adalah adanya keragaman ilmu sesuai obyek dan alatnya. Karena itu penting dikaji hubungan antar ragam obyek dan alat ilmu atau iptek tersebut. 
Topik: Pendidikan Islam dalam GBHN dan Realitas Kebangsaan, Abdul Munir Mulkhan

Demikian pula hubungan realitas alam dan sosial-humaniora atau sunnatullah dengan teks verbal Al Quran dan Sunnah. Tidak dapat diabaikan adalah masalah hubungan antara alat indera, akal dan intuisi serta logika spekulatif.

Dalam kenyatannya, iimu adalah awal yang pertama baru sesudah itu iman seperti terlihat dalam lima ayat surat Iqra' dan sikap Malaikat ketika Tuhan mencipta manusia (Adam). Untuk itu, konsep kesatuan ilmu dan realitas hampir seluruh filsuf muslim seperti telah dikemukakan, perlu dijadikan referensi. Demikian pula dalam konsep paralelisme ilmu kealaman dan sosial-humaniora dengan ilmu keagamaan.

Kesatuan hirarhis realitas, alat ilmu, ifmu-iman, menjadikan ilmu empiris, awal ilmu metafisis. Ilmu alam dan sosial-humaniora adalah awal ilmu ketuhanan (tauhid). Di antara itu terletak ilmu rasional realitas non-empiris yang berujung pada ilmu filsafat.

Seluruh unsur dasar realitas terendah pelikan terangkat dalam wujud tumbuhan dan hewan, terakhir manusia (lihat Schumacher dan pandangan filsuf muslim awal di atas). Hanya manusia-lah yang memiliki kemampuan menyadari dan menilai dirinya sendiri. Penilaian diri adalah dasar kemampuan manusia melewati setiap tingkat realitas mencapai pengetahuan mengenai Tuhan sebagai realitas tertinggi metafisis (gaib) dan dasar keyakinan tauhid.

Kesatuan hirarhis realitas dan iptek di satu pihak, serta kesatuan sistematis iptek dan iman di pihak lain, adalah dasar bagi pengembangan pendidikan Islam di semua jenis, jalur dan jenjang. Untuk itu, pengembangan dan penyelenggaraan pendidikan Islam harus memperhatikan tiga persoalan pokok. Pertama, penegasan fungsi paradigmatik tujuan holistik pendidikan Islam. Kedua, pendidikan Islam perlu dilihat dari wawasan sistemik iptek dan Pendidikan
Nasional. Ketiga, fungsi pendidikan agama Islam sebagai kurikulum wajib semua jenis, jalur dan jenjang pendidikan (psl 39 ayat 2, UUSPN/2/89). Persoalan ketiga ini diterjemahkan bukan hanya sebagai pemberi arah dan dasar etik pengembangan iptek tetapi sekaligus sebagai wacana iptek itu sendiri.

\section{Pengembangan Metodologi Pendi- dikan Islam}

Persoalan pendidikan Islam, pada akhirnya ialah penyajian bahan dan proses ajar-belajar dalam sistem pendidikan nasional (baca; umum). Berdasar kesatuan ilmu di atas, problem PAI adalah sistematisasi pokok bahasan dan kemampuan profesional guru.

Problem berikutnya ialah penempatan bidang ibadah sebagai "ketrampilan". Karena itu dapat dicapai melalui praktikum. Sementara tauhid melalui penempatan ilmu empiris sebagai bahan ilmu metafisis ketuhanan (tauhid).

Topik bahasan, disusun sesuai struktur ilmu, tidak seperti kurikulum yang ada. Ide tauhid tersatukan dalam seluruh bahasan ilmu empiris dan rasional. Bahasan mengenai realitas alam dan sosial-humaniora selalu disertai ide tauhid didalamnya.

Guru harus profesional mengurai realitas empiris dan rasional sesuai logika fisika, biologi, kimia, matematika, antropologi, sosiologi, seni-budaya. Uraian ini terhubungkan dengan realitas tertinggi metafisis ketuhanan, bukan sebaliknya. Karena itu, pendidikan Islam atau khususnya pendidikan agama Islam bukan pemindahan ketakwaan guru yang belum tentu, tapi pengkayaan pengalaman bertuhan yang diperoleh peserta didik sendiri dengan bantuan guru melalui konsientisasi dan problematisasi seperti konsep Poulo Freire (Pendidikan Kaum Tertindas, LP3ES, 
Topik: Pendidikan İslam dalam GBHN dan Realitas Kebangsaan, Abdul Munir Mulkhan

1985; Pendidikan Sebagai Praktek Pembebasan, Gramedia, 1984).

Cara di atas mungkin sulit dilakukan sebagaị akibat langkanya guru profesional. Untuk itu mungkin dapat ditempuh melalui penyajian bahan sesuai logika ilmu empiris kealaman dan sosia!-humaniora. Sifat Tuhan sebagai Pencipta dijelaskan dalam uraian fisika dan ilmu keagamaan serta ilmu sosial-humaniora. Karena itu, kemampuan beibadah dilakukan melalui berbagai bentuk latihan yang dapat dimasukkan sebagai bidang "ketrampilan".

Selanjutnya dikembangkan pencapaian ketakwaan yaitu keyakinan atas Tuhan melalui abstraksi tiap tingkat realitas. Kajian Schumacher seperti telah dikemukakan, mengenai unsur dasar realitas terendah pelikan yang terangkat dalam wujud lebih tinggi tumbuhan dan hewan, terakhir manusia bisa membantu. Hanya manusia yang berkesadaran dan mampu menyadari dirinya dalam realitas alam dan sosialhumaniora yang akan mampu menilai dirinya sendiri sebagai makhluq yang memiliki kewajiban moral berbakti kepada Tuhan dan berfungsi menyejahterakan manusia sesamanya.

Kemampuan menilai diri sendiri itulah yang dapat dijadikan dasar bagaimana manusia melewati setiap tingkat realitas untuk mencapai pengetahuan mengenai Tuhan sebagai realitas tertinggi dan metafisis (gaib). Dalam pemikiran tasauf, konsep ini memberi inspirasi pencapaian maqammaqam secara bertahap. Karena itu, ketika Schumacher berhenti mendeskripsi realitas pada tingkat manusia, uraian selanjutnya bisa mempergunakan teori emanasi.

Dalam teori emanasi, hanya manusia yang memiliki kualitas ketuhanan dan atau kemalaikatan, sehingga melalui transendensi akan memasuki kawasan yang dalam konsep tasauf dikenal sebagai al hijab. Penyingkapannya dapat dilakukan melalui abstraksi (meditasi) agar manusia mencapai maqam syahadah dan kasyf (Titus Burckharrdt, Mengenal Ajaran Kaum Sufi, Pustaka Jaya, 1984). Proses bertahap dari pendekatan emanasi itu mungkin dapat dijadikan dasar dalam menyusun tahapan pendidikan dan struktur kurikulum pendidikan Islam dan khususnya pendidikan agama Islam.

\section{GBHN sebagai Bahan Pengem- bangan Strategi Pendidikan Islam}

Kesatuan wawasan, etik dan metodologi iptek dan tauhid serta ilmu keagamaan (Islam) tersebut adalah prinsip dasar pengembangan pendekatan kultural pengembangan strategi kebijakan pendidikan Islam dalam realitas kebangsaan yang garis besarnya tertuang dalam GBHN. Berbagai persoalan mengenai konsep, tujuan, teori, metodologi dan pengembangan kurikulum pendidikan Islam, pada akhirnya perlu dikembangkan sesuai dengan realitas kehidupan umat, masyarakat dan bangsa tersebut.

Persoalan tersebut dapat dikaji dari konsep, posisi dan dasar kebijakan pendidikan dalam GBHN. Termasuk berbagai masalah dan konsep pembangunan khususnya yang berkaitan dengan kehidupan keagamaan. Cita-cita bangsa sebagaimana tercermin dalam GBHN, merupakan bahan utama dalam pengembangan strategi pendidikan Islam. Muatan pendidikan Islam sebenarnya cukup kaya tertuang dalam GBHN. Namun rumusan itu masih memerlukan kritik ulang sesuai dengan konsep dasar pendidikan Islam. Selain itu, rumusan GBHN itu juga perlu diterjemahkan dalam rumusan dengan pola kalimat yang lebih teoritis, fungsional dan operasional.

Masalah tersebut, tidak hanya mengenai program-program umum pembangunan di bidang pendidikan khususnya pendidikan 
Topik: Pendidikan Islam dalam GBHN dan Realitas Kebangsaan, Abdul Munir Mulkhan

agama. Hal ini meliputi persoalan yang lebih besar berkaitan dengan rumusan tujuan, target, sasaran dan arah pembangunan itu sendiri. Namun adalah jelas, bahwa kritik dan penerjemahan rumusan itu penting untuk tetap diletakkan pada kerangka kebangsaan, sehingga dibuat dalam format yang lebih umum mengenai bidang keagamaan di satu pihak, tetapi juga mengenai seluruh bidang kehidupan kebangsaan lainnya. Dalam hubungan ini, masalah wawasan keIslam-an dan ke-pendidik-an Islam menjadi persoalan kunci.

Untuk memperjelas persoalan akan dikemukakan beberapa contoh rumusan GBHN mengenai konsep umum pembangunan dan atau khususnya pendidikan dan lebih khusus lagi pendidikan keagamaan. Dalam GBHN 1993 dinyatakan bahwa: "Titik berat Pembangunan Jangka Panjang Kedua (pangkajang dua/pen) diletakkan pada bidang ekonomi, ...". Rumusan GBHN seperti ini, sudah tentu akan mempengaruhi berbagai produk kebijakan pembangunan. Namun karena itu pula menjadi penting perlu dicermati secara kritis, karena dalam batas-batas tertentu dapat melahirkan kebijakan dan praktek pembangunan yang bisa menyimpang dari ide dasar pendidikan Islam.

Semangat ekonomis seperti dapat dipahami dari rumusan GBHN tersebut, bisa menumbuhkan sikap materialistis yang pada akhirnya membuat manusia tidak peduli pada harkat kemuliaan kemanusiaan sebagai esensi pesan ajaran Islam. Mungkin rumusan seperti itu bisa diubah menjadi: "diletakkan pada kesejahteraan ekonomi atau ekonomi kesejahteraan". Atau lebih mendasar jika diubah menjadi: "diletakkan pada pemuliaan kemanusiaan". Jika pengubahan semacam ini sulit dilakukan karena berbagai masalah politik, mungkin rumusan seperti itu dapat ditambah dengan kata penegas seperti "... pada bidang ekonomi bagi pemuliaan kemanusiaan".

Di bidang pendidikan, pendekatan dan wawasan semacam itu dapat dipergunakan dalam usulan rancangan GBHN 1998. Sekedar contoh, berbagai konsep seperti "manusia yang utuh", "keseimbangan lahir dan batin", "ketakwaan terhadap Tuhan Yang Maha Esa", dan berbagai formulasi lainnya, perlu dipertegas dengan membuat rumusan berdasar substansi pesan ajaran Islam. Karena itu rumusan-rumusan tersebut dikembangkan berdasarkan ide "pemuliaan kemanusiaan" seperti "manusia yang sejahtera secara ekonomis dan memiliki kejujuran, bersikap adil, disiplin, kreatif dan terbuka menerima kritik. tekun beribadah" dan banyak prinsip pemuliaan kemanusiaan lainnya.

Masalah ini secara menyeluruh akan meliputi semua unsur GBHN sebagaimana dapat dilihat dari sistematisasi susunan GBHN tersebut. Karena itu masalah pengembangan strategi pendidikan Islam tidak hanya mengenai jumlah jam pendidikan agama Islam di sekolah dan atau pun madrasah, tetapi dapat dikembangkan melaluı pendekatan seperti telah dikemukakan. Untuk itu diperlukan tinjuan kritis terhadap berbagai konsep dan teori pendidikan Islam baik pada pengertian, tujuan, metodologi hingga kurikulum dan proses dan penyelenggaraan belajar-mengajar.

Pengembangan atau bahkan perubahan berbagai rumusan dalam GBHN tersebut menjadi penting bagi usaha pengembangan strategi pendidikan islam yang lebih sistematis dan integral. Pengembangan strategi pendidikan Islam dalam sistem pendidikan nasional harus diletakkan sebagai pengembangan kedudukan pendidikan agama sebagaimana maksud Undang-undang Pendidikan Nasional. Karena itu pendidikan Islam harus dikembangkan sehingga membuat manusia peserta didik menjadi semakin kreatif. 
Topik: Pendidikan Islam dalam GBHN dan Realitas Kebangsaan, Abdul Munir Mulkhan

Salah satu fungsi penting dari pendidikan ialah sebagai usaha manusia melestarikan nilai dan kebudayaan sekaligus mengembangkan iptek dan tata kehidupan dalam masyarakat masa depan. Pendidikan bukan sekedar sebagai transfer nilai dan iptek, tetapi sekaligus sebagai pengembangan kemampuan belajar untuk hidup. Karena itu kondisi awal peserta didik dan masyarakatnya adalah titik tolak usaha bertahap berkesinambungan tersebut dan secára makro kebangsaan tertuang dalam GBHN.

GBHN adalah merupakan bentuk pengamalan Pancasila yang secara moral dan politik mengikat lembaga negara dan semua warga negara. Ketetapan MPR Nomor 11/MPR/1993 menyatakan bahwa: "GBHN adalah haluan negara tentang pembangunan nasional dalam garis-garis besar sebagai pernyataan kehendak rakyat yang ditetapkan MPR setiap lima tahun". Karena itu GBHN berfungsi sebagai pemberi arah perjuangan bangsa dalam mewujudkan citacita kemerdekaan.

Selain itu, GBHN adalah konsepsi pembangunan jangka panjang (pangkajang) bertahap yang meliputi seluruh aspek kehidupan. Tahapan pangkajang adalah rangkaian program 25-30 tahun yang berkesinambungan. Pangkajang 25 tahun tahap pertama telah dimulai sejak tahun 1969 hingga berakhir tahun 1994. Dálam GBHN termuat rancangan dasar pembangunan nasional sebagai langkah konsepsional menghadapi persoalan dan permasalahan hidup manusia di tengah-tengah kehidupan sosialnya (Moertopo, 1981, hal. 5-10). Konsepsi ini tertuang dalam konsideran ketetapan MPR mengenai GBHN.

Berbeda dari sebelumnya, GBHN 1993 menuangkan rumusan mengenai kaidah penuntun yang terdiri dari 10 butir (pasal 1 . huruf $G$ ). Dua hal penting yang perlu dicermati mengenai kaidah ini, pertama ialah penempatan prinsip pendidikan kreatif sebagai satu butir tersendiri, masuknya prinsip kejujuran dan keadilan dalam berusaha dan berpolitik. Kedua, perumusan lebih operasional butir ke empat mengenai "bahwa kehidupan beragama dan kepercayaan terhadap Tuhan Yang Maha Esa, merupakan usaha bersama menciptakan landasan spiritual, moral dan etik pembangunan". Penciptaan landasan spiritual, moral dan etik dalam rumusan ini perlu lebih dipertegas seperti prinsip kejujuran dan keadilan tersebut.

Demikian pula mengenai peningkatan kualitas sumber daya manusia (SDM) yang dalam GBHN 1993 mulai muncul dengan kuat bersamaan dengan pengembangan iptek. Rumusan-rumusan semacam ini banyak diketemukan dalam semua bab dan sub bab GBHN. Sebagai contoh dalam hal pembangunan pendidikan dan pembinaan anak, remaja dan pemuda, pembangunan iptek, kehidupan beragama butir 11, 14. 15,16 huruf $F$ mengenai "arah pangkajang kedua". Demikian pula mengenai prioritas pembangunan sub bab $D$ dan sasaran sub bab E. Sementara kebijaksanaan pelita keenam yang tetap bertumpu pada trilogi pembangunan yaitu: pemerataan, pertumbuhan ekonomi, stabilitas nasional yang sehat dan dinamis, juga perlu diberi nilai operasional seperti telah dikemukakan.

Walaupun sudah sangat terlambat. kajian menyeluruh terhadap GBHN dapat dilakukan oleh lembaga pendidikan tinggi Islam seperti UIl dan perguruan tinggi swasta Islam serta IAIN sebagai pemrakarsa. Upaya ini dapat dimulai dengan kegiatan seminar untuk mempertegas persoalan dan kemudian dibentuk sebuah tim peneliti khusus mengenai $\mathrm{GBHN}$ dan realitas kehidupan umat dalam konteks kebangsaan. Hasil penelitian itu merupakan bahan untuk perumusan strategi dan kebijakan pendidikan Islam sebagai sumbangan bagi 
Topik: Pendidikan Islam dalam GBHN dan Realitas Kebangsaan. Abdul Munir Mulkhan

penyusunan GBHN 1998. Namun lebih dari itu, hasil penelitian tersebut dapat dipergunakan sebagai bahan bagi pengembangan strategi dan kebijakan perguruan tinggi lslam itu sendiri.

\section{Bahan Pustaka}

Bakr, O., 1997, Hirarki Ilmu, Mizan, Bandung.

Burckharrdt, T., 1984, Mengenal Ajaran Kaum Sufi, Pustaka Jaya, Jakarta.

Freire, P., 1985, Pendidikan Kaum Tertindas, LP3ES, Jakarta.

- 1984, Pendidikan Sebagai Praktek Pembebasan, Gramedia, Jakarta.

Fromm, E., 1995, Masyarakat Sehat, Obor, Jakarta.

Goleman, D., 1996, Emotional Intelligence, Gramedia, Jakarta.

Hadiwijono, H., 1980, Sari Sejarah Filsafat Barat I \& II, Kanisius, Yogyakarta.

Hawking, S., 1994, Riwayat Sang Kala; dari Dentuman Besar hingga Lubang Hitam, Pustaka Utama Grafiti, Jakarta.

_. 1995, Black Holes and Baby Universes; Lubang Hitam dan Jagat Bayi; dan Esei-esei Lain, Gramedia, Jakarta.

Huntington, S.P., 1993, Benturan Kebudayaan ?, Al Jami'ah No. 53 Th 1993, Jurnal Ilmu Pengetahuan Agama Islam, IAIN Sunan Kalijaga, Yogyakarta.

Huntington, S.P., 1995, Gelombang Demokratisasi Ketiga, Pustaka Utama Grafiti, Jakarta.

Izutsu, T., 1994, Konsep Kepercayaan dalam Teologi Islam; Analisis Semantik Iman dan Islam, Tiara Wacana, Yogyakarta.

, 1993, Konsep-Konsep Etika Religius dalam Qur'an, Tiara Wacana, Yogyakarta.
Mulkhan, A.M., 1994, Paradigma Intelektual Muslim; Pengantar Filsafat Pendidikan Islam dan Dakwah, cet 2, Sipress, Yogyakarta. , 1995, Teologi Kebudayaan dan Demokrasi Modernitas, Pustaka Pelajar, Yogyakarta.

__ 1995, "Islam dan Kebudayaan Kritis" dalam Kompas, 10 Oktober 1995, hlm 4-5.

, 1995, "Gagasan Tauhid Sosial dan Agenda Publik Keagamaan", Kedaulatan Rakyat, 23 Nopember 1995, hlm 4.

Mutahhari, M., 1986, Masyarakat Dan Sejarah; Kritik Islam atas Marxisme dan Teori Lainnya, Mizan, Bandung.

Nabi, M.b., 1994, Membangun Dunia Baru Islam, Mizan, Jakarta.

Naisbitt, J., 1994, Global Paradox, Binarupa Aksara, Jakarta.

Naisbitt J., \& Patricia Aburdene, 1990, Sepuluh Arah Baru untuk Tahun 1990-an; Megatrends 2000, Binarupa Aksara, Jakarta.

Nasr, S.H., 1997, dalam Hirarki Ilmu, Osman Bakar, Mizan, Bandung.

- . 1994, Islam Tradisi di Tengah Kancah Dunia Modern. Pustaka. Bandung.

Nasution, 1982, Teknologi Pendidikan, Jemmars, Bandung.

Rahman, F., 1984, ljtihad, Pustaka, Bandung.

Sardar, Z., 1992, Rekayasa Masa Depan Peradaban Muslim, Mizan, Bandung.

Sardar, Z., 1989. Sains, Teknologi Dan Pembangunan di Dunia Islam, Pustaka, Bandung.

Schumacher, E.F., 1985, Kecil Itu Indah, LP3ES, Jakarta.

, 1981, Keluar Dari Kemelut, LP3ES, Jakarta.

GBHN, 1993.

Kompas, 9 Mei 1997.

Undang-undang Sistem Pendidikan Nasional Nomor 2 Tahun 1989. 